\title{
Towards an automated procedure for the quantitative cytological screening of cervical neoplasms
}

\author{
AM SINCOCK, J MIDDLETON, D MONCRIEFF* \\ From the Biology Department, Queen Elizabeth College, London W8 7AH and the *Institute of Cancer \\ Research, Sutton, Surrey SM2 5PX
}

SUMMARY Integrating microdensitometry has been used to quantify the glycoprotein, epithelial membrane antigen (EMA), which is frequently expressed on the cytoplasmic membrane of neoplastic cells of the cervix uteri. The technique was able to identify and quantify the antigen over a wide concentration range and could also be semi-automated using a microcomputer interfaced to the microdensitometer and programmed with the simple high level language BASIC.

Widespread reference has been made elsewhere to the application of microcomputer technology to quantitative cytological assessment. ${ }^{1-3}$ More specifically, the quantitative screening of neoplasms has also been referred to 4 and in particular, the concept of automated analysis of exfoliated cells of the cervix uteri. ${ }^{5}$ We have investigated the possibility of quantifying epithelial membrane antigen (EMA) glycoprotein bound to the plasma membrane of neoplastic cells of the cervix by means of an integrating microdensitometer. In order to test whether our quantification technique could be automated we have also used a computer programme written in BASIC.

The EMA glycoprotein is confined to but widely distributed in epithelial tissues and the tumours derived from them. ${ }^{6}$ It has been identified in the metastatic deposits of primary breast carcinoma, ${ }^{67}$ some carcinomas of the skin $^{8}$ and in cervical intraepithelial neoplasia. ${ }^{89}$

\section{Material and methods}

Cervical smears were taken in the conventional manner using a wooden Ayres spatula which was immediately placed in $5 \mathrm{ml}$ of Cellfix ${ }^{10}$ solution where it remained for at least $24 \mathrm{~h}$. Smears were then prepared as described previously. ${ }^{9}$ Those from women with known cervical intraepithelial neoplasia (CIN) were taken at the Colposcopy Clinic just prior to assessment and treatment. The normal smears were taken at routine gynaecology clinics as second samples, the first being sent for Papanicolaou staining classification. ${ }^{11}$ In this preliminary study we analysed 11 smears, three with each grade of CIN and two which were cytologically normal.

The indirect alkaline phosphatase method for immunocytochemistry was used for the detection of EMA. ${ }^{12}$ Briefly, smears were incubated for $60 \mathrm{~min}$ with a suitable dilution of rabbit antiserum, then washed and incubated for the same period with the enzyme-conjugated second antibody. The stain was developed in a solution of naphthol AS-BI phosphate and Brentamine Fast Red. All smears were processed together to eliminate variation between experiments. At least 20 EMA-negative, and where possible 20 EMA-positive cells, were measured from each smear using a Vickers M86 microdensitometer with a $\times 40$ objective, a scanning spot size of $0.5 \mu \mathrm{m}$ and a closing mask of $13 \mu \mathrm{m}$ diameter (type A3). Previous calibration with an EMApositive cell (Fig. 1) had indicated an optimal wavelength of 500 or $570 \mathrm{~nm}$. Four measurements were made on the membrane of each cell and the results expressed in terms of the optical density recorded by the microdensitometer. Readings were also taken with the microdensitometer interfaced with a Research Machines $380 \mathrm{Z}$ microcomputer (Fig. 2). Under the control of a BASIC programme the microcomputer could process results taken directly from the instrument.

\section{Results}

The calibration curve for the alkaline phosphatase reaction product (Fig. 1) was plotted using the mean of readings taken in triplicate. The curve showed peaks of maximum absorption at wavelengths of 500 and $570 \mathrm{~nm}$, all measurements being subsequently carried out at $500 \mathrm{~nm}$. The results from the smears 


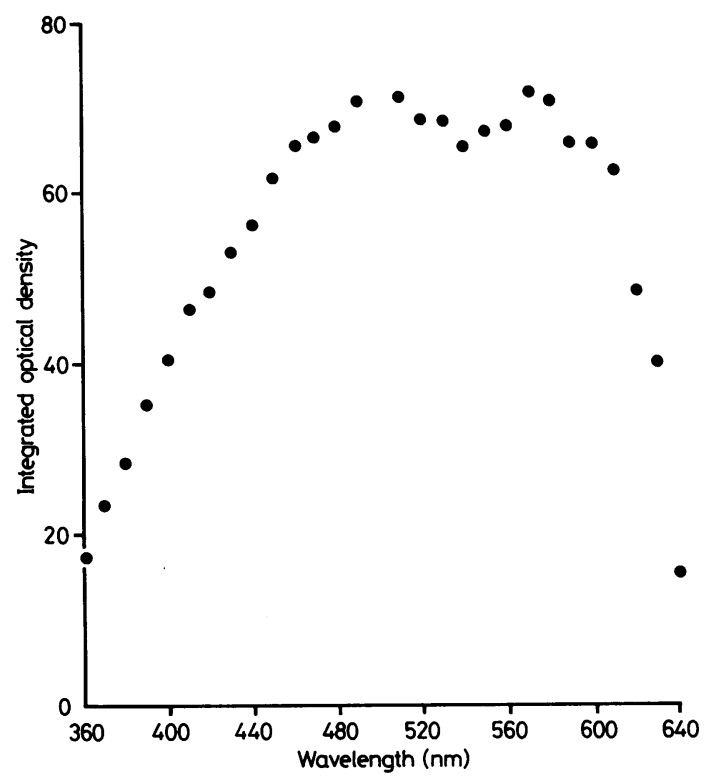

Fig. 1 Integrated optical density in arbitrary units for an EMA-positive cell sample over a range of wavelength settings.

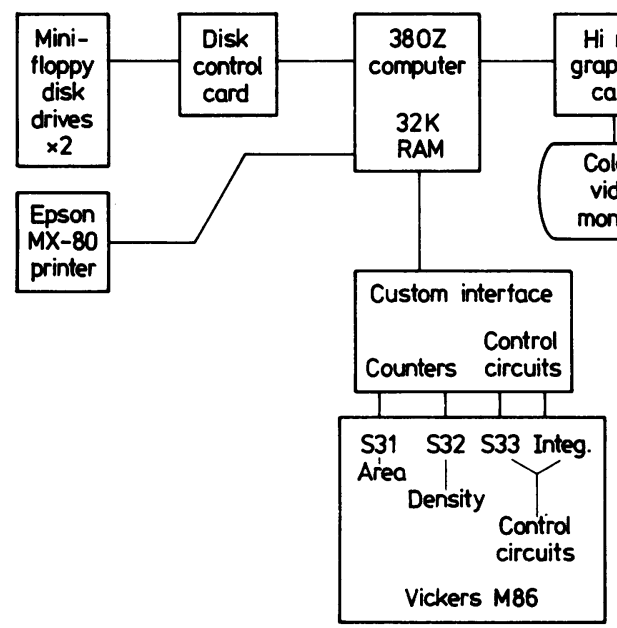

Fig. 2 Schematic diagram of the Research Machines $380 Z$ computer system and its interface coupling to a Vickers M86 integrating microdensitometer.

(Fig. 3) showed that while no positive cells were detected in the cytologically normal smears it was possible using microdensitometry to distinguish quantitatively between EMA-positive and -negative cells in the CIN grades. Where possible 20 positive cells were measured for each patient, although this

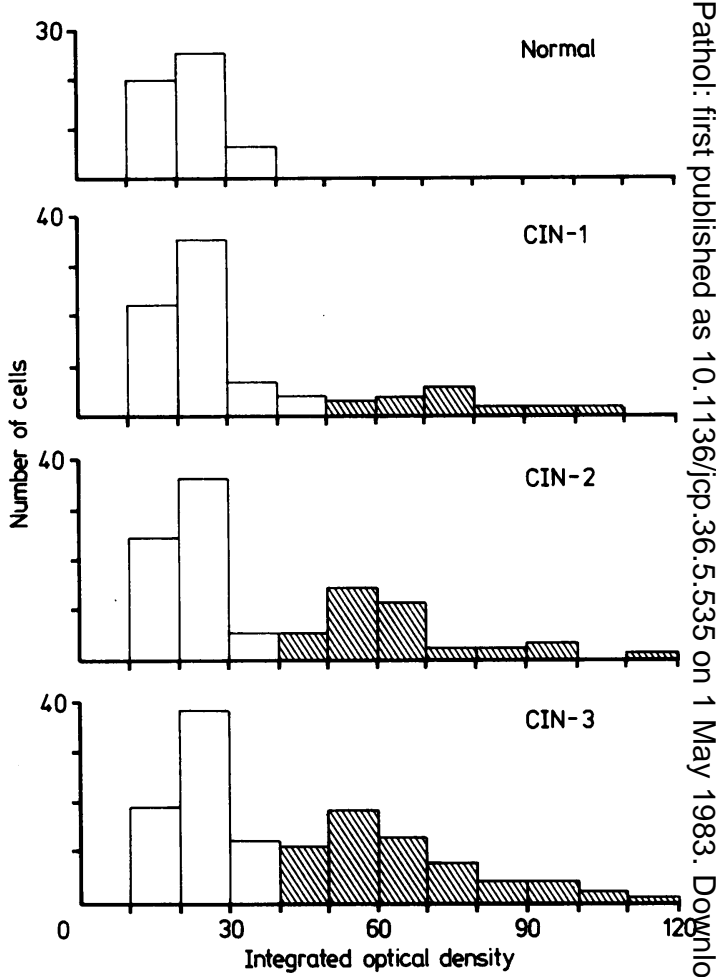

Fig. 3 Histograms showing the integrated optical densitie. for cytologically normal and abnormal cells from both $\mathbb{Q}$ normal and CIN grade 1-3 patients. The bars representing $\Rightarrow$ cytologically abnormal cells are shaded while those representing normal cells are unshaded.

became impractical at the lower CIN grades wherese the number of cells expressing the antigen became severely reduced. In some cases the values of posi tive results differed only slightly from the negativi readings. However, the smears derived from the CIN grade patients always included positive cells whose optical density per unit area of membrane was at least double that of the highest reading negae tive cells in the same smear. Positive reading showed a relatively wide distribution which cons trasted with the narrower spread of negative results and appeared unrelated to CIN grade. The max imum standard deviations for the positive cells dif not indicate wide differences between the fouk membrane measurements made for each cell.

Our results confirmed earlier reports ${ }^{13}$ that the concentration of EMA was highest for cells occur: ring singly without contact with other malignan $\bar{E}$ cells. In some instances we observed weak antiger expression which was associated with obviousl $x^{\circ}$ damaged or injured tissues, results which weref excluded from this present study. 


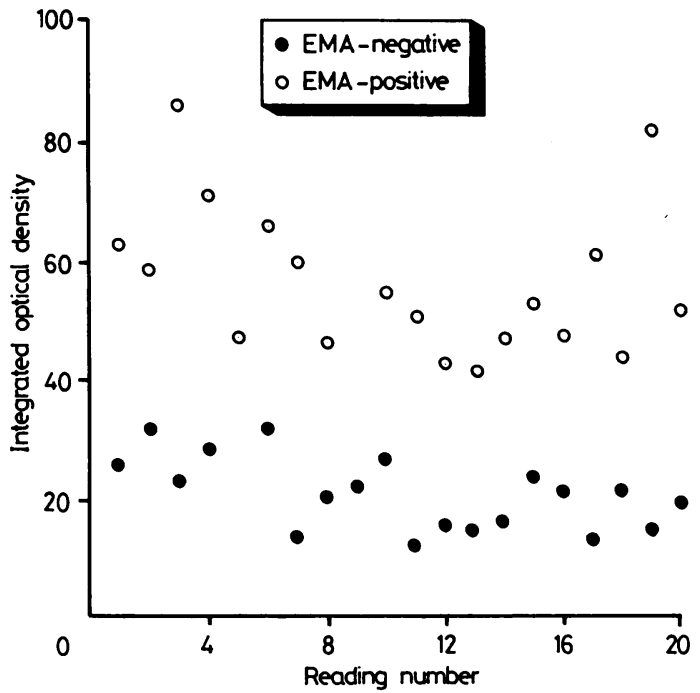

Fig. 4 A computer graphics display illustrating the ability of the microcomputer to distinguish between EMA-negative (O) and -positive (O) cells on the basis of integrated optical density.

A Research Machines $380 \mathrm{Z}$ computer interfaced with the microdensitometer and using a simple programme written in BASIC could reliably distinguish between EMA-positive and -negative cells on the basis of integrated optical density measurements (Fig. 4). The Figure shows two superimposed high resolution graphic displays of positive and negative results for one of the CIN 3 grade patients.

\section{Discussion}

The rationale behind the current investigation was to test the possibility of quantifying the EMA glycoprotein test by using integrating microdensitometry. Traditionally this has usually been applied to the measurement of nuclear rather than membrane chromophores; however, quantification of membrane areas may be sucessfully carried out with this technique. In the current investigation we were assisted by the homogeneity of the alkaline phosphatase reaction product which gave a standard deviation in the quadruple sets of readings carried out on each cell that was small in relation to the magnitude of the readings obtained. Similarly, the maximal expression of the antigen appeared with isolated cells rather than dense aggregates. This assisted microdensitometry but may also have explained the relatively wide distribution of positive readings, lower positive values of antigen being expressed by some attached cells nevertheless suitable for analysis. Even at the lower values the reac- tion product could still be distinguished and quantified by microdensitometry. We noted the weak expression of antigen in some obviously damaged cells which may be linked to the protective role previously cited for EMA. ${ }^{8}$

A preliminary test of the method as a candidate for automated cytological approaches showed that it was possible by using a simple programme written in BASIC for a microcomputer to distinguish between EMA-positive and -negative readings taken directly from the microdensitometer. Recent developments in automated cytology procedures have adopted the Quantimet 720D Image Analysis system combined with a Plumbicon light pen selection technique. ${ }^{14}$ The results obtained using a rudimentary automated approach indicate that there appears to be no reason why a sophisticated microcomputer system of this type could not be applied to the EMA glycoprotein test.

This work was financially supported by "Quest for a Test for Cancer” (Regd charity no 284526).

\section{References}

' Hecht RM, Schomer DF, Oró JA, Bartel AH, Hungerford EV. Simple adaptations to extend the range of flow cytometry five orders of magnitude for the DNA analysis of uni- and multicellular systems. J Histochem Cytochem 1981;29:771-4.

${ }^{2}$ Rasch EM, Rasch RW. Applications of microcomputer technology to cytophotometry. J Histochem Cytochem 1979;27:1384-7.

${ }^{3}$ Tanke HJ, van Ingen EM, Ploem JS. Acriflavine-Feulgen Stilbene staining: a procedure for automated cervical cytology with a television based system (LEYTAS). J Histochem Cytochem 1979;27:84-6.

${ }^{4}$ Millet JA, Husain OAN. Analysis of chromatin in carcinoma in situ. In: Pattison JR, Bitensky L, Chayen J, eds. Quantitative cytochemistry and its applications. London and New York: Academic Press, 1979:37-42.

${ }^{5}$ Millet JA, Husain OAN, Bitensky L, Chayen J. Feulgenhydrolysis profiles in cells exfoliated from the cervix uteri: a potential aid in the diagnosis of malignancy. J Clin Pathol 1982;35:345-9.

- Sloane JP, Ormerod MG, Imrie SF, Coombes RC. The use of antisera to Epithelial Membrane Antigen in detecting micrometastases in histological sections. $\mathrm{Br} J$ Cancer 1980;42:392-8.

' Dearnaley DP, Sloane JP, Ormerod MG, et al. Increased detection of mammary carcinoma cells in marrow smears using antisera to Epithelial Membrane Antigen. Br J Cancer 1981;44:85-90.

Sloane JP, Ormerod MG, Carter RL, Gusterson BA, Foster CS An immunocytochemical study of the distribution of Epithelial Membrane Antigen in normal and disordered squamous epithelium. Diag Histopathol 1982;5:11-17.

9 Moncrieff D, Ormerod MG, Coleman DV. Immunocytochemical staining of cervical smears for the diagnosis of cervical intraepithelial neoplasia. (manuscript submitted)

${ }^{10}$ Husain OAN, Page-Roberts B, Millar J. A sample preparation for automated cervical cancer screening. Acta Cytol 1978;22:1-8. 
"Papanicolaou GN. A new procedure for staining vaginal smears. Science 1942;95:432.

${ }^{12}$ To A, Coleman DV, Dearnaley DP, et al. Use of antisera to Epithelial Membrane Antigen for the cytodiagnosis of malignancy in serous effusions. J Clin Pathol 1981;34:1326-32.

${ }^{13}$ Sloane JP, Ormerod MG. Distribution of Epithelial Membrane Antigen in normal and neoplastic tissues and its value in diagnostic tumour pathology. Cancer 1981;47:1786-95.
${ }^{14}$ Sklarew RJ. Simultaneous Feulgen densitometry and autoradiographic grain counting with the Quantimet 720D Image Analysis System-1. J Histochem Cytochem 1982;30:35-48.

Requests for reprints to Dr AM Sincock, Department of Biology, Queen Elizabeth College (University of London), Campden Hill Road, London W8 7AH, England.

\section{The April 1983 issue}

\section{THE APRIL 1983 ISSUE CONTAINS THE FOLLOWING PAPERS}

\section{Review Article}

Clinical pathology of alcohol V MARKS

Heterogeneity of HLA-DR-positive histiocytes in human intestinal lamina propria: a combined histochemical and immunohistological analysis WS SELBY, LW POULTER, S HOBBS, DP JEWELL, G JANOSSY

Observer variation in the histological grading of rectal carcinoma GDH THOMAS, MF DIXON, NC SMEETON, NS WILLIAMS

Histopathological systems of breast cancer classification: reproducibility and clinical significance B STENKVIST, E BENGTSSON, O ERIKSSON, T JARKRANS, B NORDIN, $S$ WESTMAN-NAESER

Oestrogen receptor assay of cryrostat sections of human breast carcinomas with simultaneous quantitative histology JCE UNDERWOOD, VJM DANGERFIELD, MA PARSONS

Application of ELISA for assessment of antiserum immunoreactivity in endocrine immunocytochemical studies AC NIEUWENHUIJZEN KRUSEMAN

Immunoperoxidase techniques; the deleterious effect of sodium azide on the activity of peroxidase conjugates TC RICHARDSON, DEBORAH V CHAPMAN, EADIE HEYDERMAN

Biochemical and histopathological studies on patients with mucopolysaccharidoses, two of whom had been treated by fibroblast transplantation JULIE CROW, DOROTHY A GIBBS, WENDY COZENS, ELIZABETH SPELLACY, RWE WATTS

Type III glycogenosis presenting as liver disease in adults with atypical histological features IW FELLOWS, JS LOWE, AL OGILVIE, A STEVENS, PJ TOGHILL M ATKINSON

Food-starch granulomatous peritonitis JD DAVIES, ID ANSELL
A novel immunoradiometric assay for human livero ferritin A AL-SHAWI, ANNE DAWNAY, J LANDON Hypothesis: the aplastic crisis of hereditary spherocytosis is due to a single transmissibleo agent PP MORTIMER

Impairment of neutrophil chemotaxis by serum from patients with chronic lymphoproliferative dis $\stackrel{\mathscr{N}}{<}$ ease U JAYASWAL, S ROPER, S ROATH

Demonstration of pathogenic bacteria in "sterile" inflammatory exudates RC BRIDGER

Prophylaxis for infective endocarditis: antibiotic sensitivity of dental plaque TW MACFARLANE, DAŌ McGOWAN, K HUNTER, D MACKENZIE

Grouping and detection of group B streptococci by immunofluorescence D CASTLE, JANE DEELEY, CSFŌ EASMON

Counterimmunoelectrophoresis in the serodiagnosis of Legionnaires' disease MG HOLLIDAY

Significance and value of the Widal test in the diag? nosis of typhoid fever in an endemic area T PANG SD PUTHUCHEARY

Minimal criteria for the identification of Gardnerellå vaginalis isolated from the vagina JLS JOLLY

Contamination of specimen container surfaces dur ing sputum collection BW ALLEN, JH DARRELL

Technical method

A reduced incubation period for the destruction of somatic adenosine triphosphate in urines specimens PW McWALTER, CA SHARP, GE STERN

\section{Letters to the Editor}

Book reviews

Notice

Some new titles

Copies are still available and may be obtained from the PUBLISHING MANAGER.

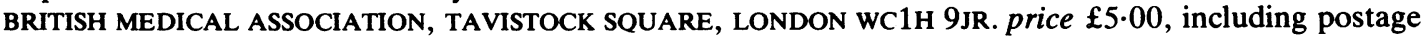

